\title{
Concept "Family" and Its Metaphorical Models in the Mari and Finish Paroemiae
}

\author{
Svetlana L. Yakovleva \\ Galina N. Kazyro \\ Marina A. Pershina \\ Tatyana A. Soldatkina \\ Ekaterina E. Fliginskikh \\ Mari State University, Yoshkar-Ola, Russia \\ Email: Zavkaf1@gmail.com
}

\section{Doi:10.5901/mjss.2015.v6n3s7p21}

\section{Abstract}

The article presents the comparative analysis of the concept Family in the Finnish and Mari paroemiological funds, both belonging to the Finno-Ugric languages, from the point of view of their metaphorical conceptualization. We define a metaphorical model as an interaction between different conceptual spheres as a result of which new linguistic units with a figurative meaning are formed. The Finnish and Mari mentalities reflected in proverbs and sayings are characterized by three cognitive levels according to their inner form and meaning, plane of content and plane of expression. In the analyzed fragment of the linguistic worldview metaphorical paroemiae make up in the Finnish language $51 \%$ (70 out of 137 units) and in the Mari language - 74 \% (128 out of 173), which means that in the Mari paroemiological fund metaphorical conceptualization prevails. Four types of metaphors are typical of the paroemiae in both funds: anthropomorphic, naturomorphic, sociomorphic and artefact. Artefact metaphors occupy a significant place in the paroemiological funds of both languages.

Keywords: the Finnish fund of paroemiae, the Mari fund of paroemiae, concept Family, frame, anthropomorphic metaphors, naturomorphic metaphors, sociomorphic metaphors, artefact metaphors, comparative analysis.

\section{Introduction}

People and individuals belonging to different cultures and ethnoses perceive the world surrounding them differently. This fact is fully reflected in languages, particularly in idioms, proverbs and sayings, which gives us all ground to analyse national linguistic views of the world. Proverbs and sayings form a paroemiological fund of a language and research on national funds allows finding out what are peoples' values and ideals.

One of the Russian famous linguists S.G. Vorkachev emphasizes that concept is determined by the complex of cognitive and behavioral stereotypes and attitudes, the main characteristic feature of which are specific ways of thinking and behavioral reactions of an individual or a social group (Vorkachev, 2004). The definition allows concluding that the term's semantics has two components: cognitive and linguistic-cultural (Yakovleva, 2015).

The present research on the concept Family is one of the series devoted to its frame structure and metaphorical models (Yakovleva, 2015; Kazyro, 2014).

\section{Materials and Methods}

Paroemiae, which are in common use in Finland and in the Republic of Mari El, situated in the Russian Federation, the Volga-Vyatka region, are represented "in a wide variety of monolingual and bilingual dictionaries. To study the metaphorical models of the concept Family in the Finnish and Mari paroemiological views of the world the methods of conceptual analysis, linguistic analysis and generalization were used. Quantitative and statistical analysis was used to represent metaphorical paroemiae and types of metaphors in the rich proverbial wisdom of the Finnish and Mari peoples" (Yakovleva, 2015). 


\section{Results and Discussion}

Research on the family is topical due to the fact that this notion is being devalued nowadays and, unfortunately, family values are being lost. We witness a serious crisis of the family. Nevertheless, it is an indisputable fact that the institution of the family in its traditional meaning is of great importance both for the whole society and an individual. Family values are revealed in paroemiological funds of different languages; they have not lost their meaning as they contain enduring values for cultures and peoples.

In the proverbs and sayings under analysis there are proverbs containing no metaphors. Nevertheless they have a great importance provided by their didactical and educational functions. Their plane of content is not exhausted by the meaning which coincides with its inner form. The plane of content can have some pragmatic components (useful advice in difficult situations) and also positive or negative connotations of the actions and situations described in proverbs and sayings.

It is not for nothing that the Mari people call proverbs and sayings exhortations of ancestors. They emphasize:

- $\quad$ the importance of the family, especially, a large one - Кугу (тӱшка) еш дене илаш куштылго 'Life is easier when your family is large'; Ик шочшо дене шочшылан от шу 'The only child is not an offspring';

- $\quad$ the importance of the woman as wife and mother - Ÿдырамаш деч посна_сурт пустангеш 'Without the woman the house is empty'; Тӱняште первый айдеме 'Mother is the first person in the world'; 'The wife can make you rich and can make you poor, she is the support of your household';

- the role of the father in the family - Пӧръен йоча ачаже кышам тошка гын веле, шотан айдеме лиеш 'If the son follows in his father's footsteps he will be the best man';

- the importance of choosing the right partner - Аважым ончен - ӱдыржым нал, ачажым ончен - эргыжлан кай "Taking a girl for a wife look at her mother, taking a man for a husband look at his father';

- children's responsibility to parents and respect to the elder - When you respect your mother and father your life will be long (happy, good)'.

However, most proverbs are based on the metaphor. Analysing the metaphorical models of proverbs about the family we define a metaphorical model as an interaction between different conceptual spheres as a result of which new linguistic units with a figurative meaning are formed. According to E. A. Grudeva, "the linguistic image is a kind of language consciousness, which presupposes new associative relations necessary for linguistic modeling of a national culture phenomenon, as well as for the formation of the linguistic worldview in the form of visual images" (Grudeva, 2013).

The analysis of 137 paroemiae of the Finnish language identifying such a fragment of the linguistic worldview as the family allows us concluding that the Finnish view of the world represented in the paroemiology is slightly dominated by the figurative world perception, i.e. 70 proverbs versus 67 , or $51 \%$. On the other hand, proverbs of the Mari language based on the metaphor exceed in number: 173 proverbs out of $128(74 \%)$ are figurative in their meaning.

The family in the proverbs under analysis is represented as a family home, that in its turn is associated with a bird's nest, while children are regarded as younglings: Кайыкиге шулдырангеш дын, пыжаш деч мӱндырко чонгешта 'If a bird gets its wings it will fly far from its nest'; Пьжаш деч посна кайыкат ок шоч 'Even birds are not born out of the nest'; Пьжаш ыштыде кайыкат муным ок мунчо 'Even birds don't lay eggs without a nest'. The idea of having one's own home to create a family and have children as a vital importance is emphasized in the last two proverbs. The zoomorphic metaphor is also represented in the proverbs, where mother's love and its importance for children is the semantic dominant: Коракигын умшаже кутсыз гынат, аважлан пеш чевер 'Although a crown has an ugly mouth, it is the best for his mother'; Мӱкшат авадеч посна ок иле, пӱтынек пытат 'Even bees don't live without a queen bee, they will all die out'. However, an appropriate upbringing is vital for children: Туныктыдымо талгыдылан корно уке 'There is no road for the untrained yearling'.

Lost goose's and gander's images form the basis of proverbs: Тулык вате - йомшо кайыккомбо 'Widow is a lost goose'; 'If a man doesn't have a wife he is like a gander looking for water'. Hardships of a lonely person are the semantic dominant of these proverbs. The idea of the so-called dog's life is traced in the proverb: Тулык йоча пий чытымым чыma 'Orphan is as patient as a dog'.

Images of wild animals may be found in the Mari proverbs, like in the proverb that a later marriage does not promise much happiness: Жап шуэш гын, ӱдыр чодра маскаланат кая 'The time comes when a girl is eager to marry a bear'. The snake-image is associated with such human qualities as deceit and malice. This characteristic feature makes the basis for a metaphor in the proverb: Ү̈дырамашын капьштыже кум чйчалтыш кишке вйр уло 'There are three drops of snake-like blood in the female's body'.

Phytomorphic metaphors are also found in the paroemiological fund of the Mari language. A man is compared to a 
tree in some proverbs: Toшто пушенгын вожшо пенгыде (куча) - 'An old tree grasps with its roots'. This means that the elderly people have a profound background, sufficient experience and commitment to traditions. Волгенче шкет пушенгым пытара - 'The lightning strikes an only tree'. Semantic dominant of this proverb is that a lonely man is less secure than a family man. Few proverbs with the phytomorphic metaphor emphasize the importance of heredity and upbringing: Лопшудым шынден, ковышта ок шоч 'Having planted a burdock, you won't reap the cabbage'; Нӧлпыштӧ олма ок шоч 'No apples for the alder'; Кож деч кож шочеш, тумо деч тумо шочеш 'Spruce is born from spruce, oak is born from oak'.

The artifact metaphor is related to the household life, utensils, clothing, food, i.e. to everything created by man. The family is associated with a fence beyond which a person feels safe and sound: $E m$ - тазалык пече 'Family is a guard for health'; Марийдыме вате - печыдыме пакча 'Widow is like a garden without a fence'; Вате-марий кок пече менге гай лийман: иктьже йӧрлаш тӱнгалеш гын, весыжлан энгерта 'Husband and wife should be like two pillars for the fence, if one starts to fall, it relies on the other'. Family is a home: Суртьишто пӧръен уке гын, сурт-пече тулык 'The house without a man is like an orphan'; Пӧръен улмо годым ӱдырамаш пӧртын кум лукшым куча, пӧръен укеж годым - чыла ныл лукшымат 'A woman bears three corners if she has a husband, otherwise she bears all four'.

The importance of a full family is emphasized in these proverbs. The same idea is inherent in the proverb Tичмam еш тичмаш киндерке дене иктак 'A full family is like a sauce full of bread'. Food is also mentioned in proverbs: Ÿдыр налме, марлан кайыме - пучымыш кочмо гай огыл 'Marriage is not to devour porridge '(marriage is quite serious affair); 'The son-in-law and the daughter bake wild raisin cakes, while the son and his wife bake salted pies' (the Mari cherish wild raisin cakes, so the semantic dominant of this proverb is the following 'unlike the son and a daughter-in-law, the daughter and a son-in-law treat parents with love and care"); Мӱндыр родо - шӱшмо ӱй, лишыл (чак) родо кочушмен 'Distant relatives are like butter, close ones are bitter than radish' (uneasy relationship with close relatives is stressed); Пура деч ончьчч шовыжо йоген каен 'Foam poured before the brew' (i.e. a younger sister got married before the elder one, which was frowned upon).

Household goods and utensils are mentioned in the following proverbs about the family: Марий ден ватыже мужыр онгыр 'The husband and his wife are two bells' (there should be understanding and agreement between a husband and a wife); Ачаже шӱч кӧршӧк, аваже тегыт лагон гын, икшывышт эньы пырче ок лий 'If the father is a pot with soot (carbon), the mother is a barrel of tar, their children will not become a berry of raspberry' (heredity and upbringing of children is important).

The Finnish and the Mari consciousness displayed in the paroemiological funds are characterized by the organistic way of thinking. Organistic metaphors, in contrast to the rational and mechanistic metaphors have deeper roots in history. "This point is reflected in the human consciousness and, therefore, in a proverbial worldview. Man, nature and things represent the most common conceptual sources in proverbial metaphorization" (Yakovleva, 2015).

The intangible world is less popular in the conceptualization of the Finnish proverbial worldview. This statement is appropriate for the proverbial worldview of the Mari people.

The analysis of the proverbial material has shown the existence of four types of metaphors: naturomorphic, anthropomorphic, artefact and sociomorphic, according to the classification given by A.P. Chudinov (Chudinov, 2013). The examined fragment of proverbial worldview involves the presence of "the anthropomorphic metaphor: the model "Family is a Human Body". One of the most various is the frame "Parts of the Body"; parts of woman's body: breast, teats, bum; parts of man's body: beard, moustache, bold head; and non-gender differences: heart, hands" (Yakovleva, 2015).

In the Mari proverbs the frame "Parts of body" consists of such components as: "parts of child's body" - guts, ears, blood, finger, hair. The components heart, hands, face, head, legs are used both in proverbs about men and women. Thus, the archaic conscience of people is closely connected with their body or parts of the body.

Another frame "Abilities of a person" is connected with the concept of mind. "The idea that despite the satisfaction of children's material needs, their mother's milk is not enough for the development of their mental abilities is highlighted in the perception of the Finns" (Yakovleva, 2015).

In the Mari perception this frame is also connected with the concept mind, the fact that it is revealed in many proverbs about the brain proves its significance. Although this concept was not particularly revealed as the greatest attention here is paid to children's abilities to do some physical, not mental work.

People belong to nature, for that reason they conceptualize the world around them through the use of naturomorphic metaphors. This is reflected in such models as "Family is a World of Animals", "Family is a World of Plants". Particularly, in the Mari language one's family is a home, a house which is associated with a bird's nest and children - with baby birds. In several proverbs there is also the phytomorphic metaphor: family is a tree and children are its branches and fruit.

In the Finnish proverbial worldview there is a huge predominance of zoomorphic metaphors "containing the images 
of domestic animals (80\%): cock, chicken, chicks, pig, cat, horse and colt, dog and puppy, as well as parts of their bodies: wing, side, snout. The frame "Wild animals" is represented by the image of wolf" (Yakovleva, 2015). There is also one image in the frame "Fish".

In the Mari language the number of zoomorphic metaphors containing the images of domestic and wild animals is reflected in $43 \%$ of proverbs containing the image of domestic animals and $57 \%$ - of wild animals. Among wild animals it is necessary to point out the images of birds (as a collective image), hawk, raven, wolf, bear, snake, bees; among domestic animals - lamb, colt, horse, cow, pig, dog, goose and gander. The meaning of the proverbs with the image of lost goose and gander is that it is not easy for a lonely person to live. The proverbs with the image of a dog prove a hard life of an orphan.

In the Finnish proverbs the phytomorphic metaphor is more frequent than the zoomorphic one. In this segment of proverbial fund the metaphoric transfer is achieved due to the use of singular images of such trees as fur and birch and also parts of these trees: stump, and the image of spikes and fields.

For the Mari language the phytomorphic metaphor is rather typical (28\% of all naturomorphic metaphors). Analyzing its experience in understanding of such concept as family the Mari people often use the images of different plants: alder, apple-tree, pine, oak, fur, burdock, cabbage, reddish, turnip, flowers, tree (a collective image). It is necessary to point out that the image of a tree is the basis of both proverbs about family and a lonely or an old person.

"Celestial bodies" frame is represented "by the image of the sun, the frame "Day and night" - evening, "Weather" by the images of frost and cold" (Yakovleva, 2015).

In the Mari proverbs which highlight a great role of mother in the life of a child, there are images of sky and sun. The comparison of a mother with the sky and the sun can be explained by the fact that "in oral national poetry "the sky" (the sun, moon, stars) is depicted as a power that gives life to a person [5, c. 166]. Among weather phenomena there are icicles, snow, ice and lightning.

In the Finnish paroemiology the origin sphere of concepts is the artificial metaphor. "The metaphorical model "Family is a house" is presented by the images of house, building, bath-house (and sign-signal steam, bath), shed, rickyard, as well as some buildings connected with them: stove (ash as a result of its work), extinct fireplace; and parts of buildings: roof, door, side jamb. The majority of proverbs contains the images of house, bath-house and stove - the images which are closely connected with the life and household activities of a Finnish family" (Yakovleva, 2015).

In the Mari paroemiology the family is associated not only with a house as a building but with a wall that a person feels safe behind. A husband and a wife are two posts of a wall, if one falls down, the whole wall will fall down too, so the life of a family will be in danger.

The most widely represented by the Finnish proverbial metaphor is the frame "Material products of human activities": "bread, loaf of bread, wool, fabric, birch-bark box; "Articles of clothes": underwear, trousers, and headscarf; "Household items": trough, empty jug, kettle; "Tools": firestone, ax, sheath; "Food and drinks": coffee, water, soup, cakes, fat, as well as tobacco as material for smoking, oats as feed, a comb as an accessory, and a cart" (Yakovleva, 2015). The fame "Products of animals' vital activity" is represented with the image of dung and beeswax.

In the Mari language the biggest proverbial groups are "Food and drinks": porridge, cranberry cakes, salty cakes, bread, omelet, little sweets, butter, bitter reddish, kvass and "Household items": a pot with ashes, tar flank, hand-bell, spindle, iron chains, bench, broom, stick, shaft. The lesser group are "Material products of human activities": red-hot iron, silver coins, gold, towel (silk or calico), "Articles of clothes": bast shoes and "Products of vital activity": slops.

The image of a song represents the frame "Non-material products of human activity". In the Mari language such a frame has not been found at all.

Thus, the results of the research on the proverbial conceptualization show that for the Finnish and Mari proverbial mentality three cognitive levels of worldview are typical: on the first one there is co-occurrence of internal form and meaning of paroemiological units; on the second one we observe non-coincidence of their cognitive levels; on the last level "one or even more components of the internal form are included in the meaning of a proverb when two cognitive levels intersect" (Yakovleva, 2015).

The research on 137 paroemiological units, which reflect one particular element of the proverbial worldview - the family, show that for the Finnish mentality the image-bearing perception is slightly prevalent: 70 proverbs vs. 67 , or $51 \%$.

For the Mari mentality the image-bearing perception is predominant. For the Finnish proverbial worldview the artificial metaphorization is typical, while in the Mari fund it is only the second (32\%) after the naturomorphic metaphors (42\%), the third are anthropomorphic ones (26\%).

Proverbial conceptualization is closely connected with thinking of an individual who deals with exact objects, processes and phenomena. Human consciousness reflects peculiar and common features of surrounding subjects and phenomena, makes connections among them, links different conceptual spheres. The sociomorphic metaphor can be 
rarely found in the paroemiological units of both Finnish and Mari funds. "Religion as one of the forms of social perception of the world is not widely represented in the examined fragment of both proverbial worldviews. During the research only two examples of the Finnish proverbs have been found: Hang-over and a wife come from hell and It is better to marry than to live in sin" (Yakovleva, 2015).

The majority of the paroemiological units about the family reflects different contexts: cultural, ethnographical and historical as well as peculiar features of peoples' mentality. The paroemiological national funds of a language help to understand the system of values of every nation, its uniqueness and singularity.

\section{References}

Chudinov, A.P. The Cognitive-Discursive Description of Metaphorical Modal. (p. 9) http://gendocs.ru/page=9. (18.01.2013).

Explanatory Bible by Lopukhin. http://www.bible.in.ua/underl/Lop/index.htm (03.05.2013).

Finnish Proverbs and Sayings and their Russian Analogues (2011). Saint-Petersburg.

Finnish Proverbs about Family. House. Family. Relatives. Children. http://hopeakettu.narod.ru/fin3.html (10.04.2013).

Finnish Proverbs and Sayings. http://www.orator.ru/poslovicy_finskie.html (05.05.2013).

Fliginskikh E.E. Linguistic Characteristics of the Image of Wife in Idioms of the English, French and Russian Languages // Vestnik of the Mari State University. 2015. No. 17. P. 109-112.

Grudeva, E.A. (2013) The Concept осень/autumn perceived by the Russian and Englishnative speakers (based on the associative experiment), Philological Sciences, Questions of Theory and Practice, 5, V.1 (p. 44-46). Tambov.

Kazyro, G.N. (2014) Metaphorical Models of the Concept Family in the Mari language Philological Sciences, Questions of Theory and Practice, 2, V.2. Tambov.

Kitikov, A.E. (2004). Proverbs and Sayings of the Finno-Ugric Peoples. Yoshkar-Ola.

Kuznetsova, O.A., Kharchenkova, L.I. Ethnic Norms of the Russians and the Finns. http://commbehavior.narod.ru/RusFin/RusFin2001/ KuznetsovaKharchenkova.htm (20.05.2013).

Proverbs of the Peoples of the World. Finnish Proverbs and Sayings. http://mudrosti.info/pogovorki_finskie.php?\&page=2

World Sayings. Finnish Proverbs and Sayings. http://sayings.ru/world/finn/finn.html (12.05.2013).

Sayings about Family and Love. (21.06.2013).

Vorkachev, S.G. (2004). Happiness as a Linguistic-cultural Concept. Moscow.

Yakovleva, S.L., Pershina M.A., Soldatkina T.A., Fliginskikh E.E. (2015). The Frame Structure of the Concept FAMILY in the Paroemiological View of the World of the Finnish Language. Review of European Studies, Vol. 7, No. 8 (p. 253-262). Canada. 
